\section{W. W. Pigman}

Professor W. W. Pigman, former Chairman of the Department of Biochemistry at New York Medical College died on 30 September 1977, aged 67.

Ward Pigman emerged through the adversities of the Depression years and a career encompassing governmental, industrial, and academic research, as one of the most broadly based and well recognised authorities on the carbohydrates. His book Chemistry of the Carbohydrates, published in 1948, became established as the standard reference text on the subject, and earned him wide recognition among students and specialists in a multitude of disciplines for which carbohydrates have relevance: organic chemistry, biochemistry, food and nutrition, medical aspects, and industrial utilisation.

Specialists in the carbohydrate field have also benefited from the organisational capabilities of Dr Pigman, who devoted many years of endeavour to development of the area through work with the Carbohydrate Division of the American Chemical Society and later with the International Society for Complex Carbohydrates, as well as through his own research papers, numbering more than 250, and his consistent efforts to bring research on the carbohydrates to the broader audience by means of review publications, monographs, symposia and lectures, and radio broadcasts. In 1959, he was honoured with the C. S. Hudson Award of the ACS Carbohydrate Division for his outstanding contributions to the field of carbohydrates.

Born in Chicago, Pigman initiated his higher education there at a junior college, but moved to Washington, D.C. in 1930 to enter George Washington University, where he completed his B.S. and M.S. degrees while working in the laboratory of $\mathrm{Dr}$ Horace $\mathrm{S}$. lsbell at the National Bureau of Standards. He remained at the Bureau altogether until 1943, while completing his Ph.D. degree (1936) at the University of Maryland and, during $1938 \cdot 1939$, spending a period of research study at the University of Leipzig under a grant from the Lalor Foundation.

The physical-organic emphasis in Isbell's laboratory, concerned with precise analytical standards and procedures with carbohydrates, provided Pigman with a rigorous experience of accurate analytical technique, especially polarimetry, and he made important contributions to our understanding of the optical rotational and tautomeric properties of sugars and their derivatives. From this basis there developed an extensive series of investigations on enzymology, with emphasis on the glycosidases, a subject that Pigman also pursued while he was in Germany. During the later part of his stay at the Bureau of Standards, he worked on a project for the production of industrial alcohol from wheat; alcohol was then a scarce commodity needed for the war effort.

In 1943, he left the government research service and worked for a time with the Corn Products Refining Co. in Argo, Illinois, where the major interest was starch technology and utilisation. In 1946 he joined the research staff at the Institute of Paper Chemistry in Appleton, Wisconsin, to investigate various aspects of wood chemistry. During this period he became involved, with R. M. Goepp, Jr, in the planning of the book Chemistry of the Carbohydrates, which was completed by Pigman following the death of $\mathrm{Dr}$ Goepp in an accident. Dr Pigman also served as a founder of the reference series Advances in Carbohydrate Chemistry that had its debut in 1945 , and he was an editor of the first four volumes.

Together with the scientific recognition from his writings, Pigman also came into the public eye during the 'red spy' scares in 1948-1949, when he was called upon to testify before a federal grand jury in the indictment and subsequent perjury trial of Alger Hiss; accusations that Pigman was involved in a leak of government documents were proved to be untrue.

A substantial transition of emphasis toward applied biochemistry occurred for Pigman when, in 1949, he moved to the University of Alabama Medical Center in Birmingham, Alabama to become Associate Professor of biochemistry. A primary phase of his research there was concerned with the mechanism and control of dental caries, with particular emphasis on the role of carbohydrates in the incidence of tooth decay. He continued active work with the American Chemical Society in service to the Sugar (later Carbohydrate) Division in its efforts to improve exchange of information and ideas between workers from a broad range of backgrounds. He became a member of the Institute of Dental Research and the American Society of Biochemists, and his research interests progressed to detailed studies on carbohydrates of animal fluid secretions, especially hyaluronic acid. mucins, and glycoproteins.

He edited a multi-authored volume The Carbohydrates, which appeared in 1957 and brought the earlier book up to date; a subsequent edition was later prepared in collaboration with myself. In 1960, Professor Pigman moved to New York City to become Chairman of the Biochemistry Department at New York Medical College, while still retaining research connections in Alabama. He received the medal of the French Biochemical Society in 1962 and the University of Milan Medal in 1964.

Administrative duties in the new post were more substantial, especially during the years 19631968 when he served as Dean of the Graduate School of Basic Sciences. Since he could make decisions rapidly and delegate responsibility effectively, he was still able to concentrate on research, especially on mucins and glycoproteins. With his research group of seasoned investigators, he probed especially the structures of the submaxillary mucins and, never being afraid to take a controversial stand, he took issue with some of the accepted dogmas of protein biosynthesis as they apply to the formation of glycoproteins.

Sensing a need for broader contact between carbohydrate specialists and experts in other areas, particularly with respect to the complex conjugates of carbohydrates involved in biomedical problems, Professor Pigman became a founder and driving force behind the International Society for Complex Carbohydrates. He served as President of that Society and, on September 30, 1977, was attending the last day of a highly successful meeting of the Society in Woods Hole, Massachusetts, when a sudden seizure took his life. The proceedings of that meeting are dedicated to his memory. At the time of his death, he was organising a symposium on glycoproteins that will be held in Anaheim, California during March, 1978

Ward Pigman was a tall, striking figure, white-haired in his later years; in his youth he was athletic and a good 
basketball player. A great lover of the arts, especially of modern painting, theatre, and ballet, he also found much enjoyment in travel; in particular he took pleasure in sharing these activities in his later life in the company of his second wife, Gladys. He heeded little the counsel of those friends who suggested that his driving life-style was scarcely a recipe for longevity, but he lived a full and rich life with neverflagging zest for new ideas and schemes, coupled with a broad imagination and flair for accomplishment. His achievements in exploring and expounding on the most widespread group of natural products, the carbohydrates, in all of their aspects, have left a permanent impression on scientific history.

In addition to his wife, Gladys, living at their home in Jamesburg, New Jersey, Professor Pigman is survived by a brother and a sister, his sons, John and James, and daughter Jean of his first marriage, and three grandchildren.

Derek Horton

\section{H. E. Street}

Professor H. E. Street of the Department of Botany of the University of Leicester died on 4 December 1977, aged 64. The news of his death will sadden a wide range of scientists, in the U.K. and abroad, his academic colleagues and a large number of former students, research associates and many friends. Their collective sense of loss will be more acute in that the end was so unexpected.

Professor Street was in what was expected to be the last year of his active Professorship but it was known that he was planning for some more years of laboratory work in the field of his current interests. These interests fall into that area of plant physiology and of the study of growth which utilises aseptic conditions to culture erstwhile mature and quiescent tissue, to make it grow rapidly again, and whether from randomly proliferating explanted tissue or cells, to induce the development of new plants.

Professor Street's enthusiasm for this aspect of botanical work expressed itself, not only in a steady stream of research papers in the scholarly journals but also by his participation in symposia on the international level. At least as early as 1956 at Woodstock in Vermont, U.S.A. and in 1961 in Delhi, India and almost annually since then, Professor Street has been an invited guest and honoured contributor to such meetings. But more recently he lent his support to the organisation of such conferences, in part through the International Plant Tissue Culture Association which he helped to found. One such conference, widely attended at
Leicester in 1974, owed much of its success to his initiative and, in that case, he edited the resultant volume.

Throughout his career Professor Street actively fulfilled his desire to communicate science-to students and teachers whose understanding of basic biological science he cultivated and to a larger general audience who sought to comprehend the science and relate it to technology and society. He served a term as President of the Botanical Section of the British Association for the Advancement of Science, and always enjoyed demonstrating his work at scientific meetings such as those of the Society for Experimental Biology and, on occasion, at Royal Society Conversaziones.

In these various roles Professor Street was an inveterate traveller to botanical conferences whether they were large (like the last International Botanical Conference at Leningrad in 1975) or smaller (like the symposium on Plant Cell and Tissue Culture at Columbus, Ohio as recently as September 1977). At these gatherings his somewhat shaggy mane (whitening and thinning with the years) his cheerful laugh and the inevitable pipe (always being relit but never, it seemed, completely so) and his indefatigable attendance through the dullest sessions, which by his presence and questions he so of ten lightened, will be a memory that many will cherish.

Professor Street's most infectious quality was zest; an enthusiasm for the subject of botany that he always retained. But this emerged after he came to academic botany later than most. He trained first in pharmacy then obtained an external degree from London in 1939 with 1st class honours while still working at Nottingham. A Ph.D., at Birkbeck College, from London University was taken not only under the difficutlies of part-time study while being employed, but also amid the disturbances of World War II, for his research had to be moved first to his home (anticipating the wartime fate that eventually overtook the laboratory in Central London) and then to Manchester.

Professor Street's early interests involved the nitrogen metabolism of plants, and he maintained close contact with this subject for some years, but later he concentrated on the areas that finally captured his interest and loyalty. This began when he turned to the aseptic culture and nutrition and the indefinite growth of isolated root tips in liquid, at Manchester University after the completion of his doctoral degree. He was awarded a D.Sc in 1953.

Later, at Swansea, where he was to serve for 13 years as Professor of Botany in the University of Wales, Professor Street transformed the
Botany Dept. of the University College of Swansea for he presided over the building of well equipped botanical laboratories and made them an internationally known centre for the study of growth. But he sought association with a larger group of biologists and so moved to the University of Leicester.

Though one feared that an increasing administrative responsibility (he became the first Chairman of a School of Biology there) would have dampened his research ardour, this did not occur for he maintained his enthusiasm to the end. He will be sorely missed, not only by his wife and three children to whom our sympathy is extended, but as a teacher, research worker and as a protagonist for botanical science wherever botanists and plant physiologists study the problems of growth and form.

F. C. Steward

\section{Ana Conea}

Dr Ana Conea died on 4 March, 1977 in the great Bucharest earthquake. She was a leading Romanian soil scientist who had achieved particular success in the fields of soil classification and systematics. The Bucharest earthquake claimed many lives and the loss of Dr Conea, aged only 54, was particularly tragic.

She was born on $20 \mathrm{July}, 1922$ and graduated in geography from Bucharest State University in 1945. In 1966 she received her doctors degree for her work on pedogenetical formations and Quaternary deposits in central and northern Dobrudja, and this formed the basis for the book Formatiuni Cuaternare in Dobrogea which was published in 1970 by Editura Academiei, Bucharest. She also produced Guidebook 10 of the Romanian Geological Institute which deals with the loess in Romania.

Dr Conea was an active member of the Internationale Quartärvereinigung (INQUA) Loess Commission and provided the Romanian data for the INQUA loess map of Europe which is one of the Commission's major undertakings. She was also a member of the Paleopedology Commission of the International Society of Soil Science and of the ECA/FAO Group for the 1: 1.000,000 Soil Map of Europe. She published more than 90 papers during her 26 years work at the State Committee of Geology, the Geological Institute, and latterly at the Research Institute of Soil Science and Agrochemistry. She worked on the geography of Romanian soils, complex soil survey, paleopedology and paleogeography. Her main interests were in the fields of soil classification and syste- 